\title{
All-inclusiveness: The place of assistive devices for persons with disabilities in the Covid-19 pandemic era
}

Rufus Olanrewaju Adebisi, Ph.D

School of Special Education, Department of Communication \& Behaviour Disorders, Federal College of Education (Special), Nigeria aderufus2@gmail.com
Hammed Gbenga Adewale

Post Graduate school, Department of Special Education, University of Ibàdan, Nigeria gbengusy@gmail.com 


\title{
All-inclusiveness: The place of assistive devices for persons with disabilities in the Covid-19 pandemic era
}

\author{
Rufus Olanrewaju Adebisi, Ph.D* \\ School of Special Education, Department of Communication \& Behaviour Disorders \\ Federal College of Education (Special), Nigeria \\ aderufus2@gmail.com \\ Hammed Gbenga Adewale \\ Post Graduate school, Department of Special Education, University of Ibàdan, Nigeria \\ gbengusy@gmail.com
}

Received: $28^{\text {th }}$ Dec 2020 Revised: $27^{\text {th }}$ Jan 2021 Accepted: $1^{\text {st }}$ Feb $2021 \quad$ DOI: https://doi.org $/ 10.31559 / C C S E 2021.2 .1 .4$

Abstract: An efficacious confrontation to the blowing-out of Covid-19 known as coronavirus have emanated to rely comprehensively on the innovation of assistive devices to flow the indispensable information about the bearing waves of a plague inducted as "Covid-19 or Corona virus"; bridge the social gap flanked by special need condition in the midst of social separation; safeguard the robustness of persons with disabilities (across the ages) during Covid-19 pandemic and ensure the "stay safe" crusade is not epitomized with ostracism. In that case, the immersion of assistive device for swiftness of all-encompassing healthy society particularly that of persons with disabilities is preordained. Whereas handling dynamism nature of persons with disabilities on the ground of equal right with their 'abled' counterparts calls for assistive devices. This paper explores the effect of assistive devices in making persons with disabilities evolve with their essence and existence as well as playing own quota in the fight against Covid-19 pandemic. It also describes Covid-19 in relation to persons with disabilities to set a scale of balance on multiplicity nature of human using assistive devices as mechanism for inclusion of all and sundry particularly that of persons with disabilities. Therefore, saving and securing lives and livelihoods of persons with disabilities during Covid-19 era is only achievable through uncompromising influence of assistive devices.

Keyword: Covid-19; Persons with disabilities; assistive devices; coronavirus; Inclusion.

${ }^{*}$ Corresponding author

Rufus Olanrewaju Adebisi

Department of Communication \& Behaviour Disorders, Federal College of Education (Special), Nigeria

E-mail: aderufus2@gmail.com 


\section{Introduction}

The outburst of covid-19 or coronavirus is not restricted to Nigeria but a global sensation. In the essence of that, over twelve million people across the globe seem to have been infected by this deleterious virus. The oral tradition from series of sponsored radio and television programs that featured specialists in microbiology, genetic, parasitology, virology, and medical pharmacology as regard dealings with the pandemic avowed no single vaccine has been explicitly considered for its cure. Many experts in the field of medicine and surgery bank on the fact that Covid-19 is not a respecter of anybody, race, religious, social, political, or economic affiliation. The virus can be contracted both by educated and non-educated; young and old, physically fit or not. Without any iota of doubt persons with disabilities are not let out of its perilous mission, such individuals may either get ill with covid-19 or confined by the newly demand of social distancing, which is a measure in place to checkmate its spread. Moreover, the on-going campaign against Covid-19 might not be a solitary itinerary of workers in public health but a broad determination on the part of public to make all folds including persons with disabilities not defenselessness of the pandemic; and getting the psychological and physiological requirement of persons with disabilities conveyed at this period of enormity.

Yet, the protection of persons with disabilities seems not to have been greatly held with precedence even with the spread and scourge of Covid-19. This laxity may have occasioned a few persons with disabilities to have been left out of safety and active strategy of combating the virus. The flare-up of the virus has led to the shutting down of schools, courts, carriage system, social businesses, musical concerts, relaxation and leisure facilities and others cost-effective venture. Its emergence could have disrupted all and sundry including persons with disabilities off equilibrium. The affliction of Covid-19 in connection to the futility of persons with disabilities may not be fully expounded by thousands of words. For instance, it is not surprising that Nigerians including persons with disabilities were anticipating for palliative to be given in getting themselves relieved from fiscal hardship experience during lockdown and restriction enforcement by the Nigerian government as part of covid19 control measure. This might be the reason for spending close to a billion of naira on food distribution and cash transfer to the poorest of the poor and their children captured in the social welfare intervention called 'school feeding' without displaying similar gesture to persons with disabilities. That is, nothing seems to have been purportedly done as an incentive to the persons with disabilities across all ages irrespective of inequality between their monetary prowess and that of their able counterparts together with the fact that the economic undertakings of the country are under the siege of covid-19. Persons with disabilities are seemed abandoned by 
their municipals that ought to have stood by them and show the individuals the solidarity. The agony of persons with disabilities during this pandemic era may be horrifying as the survival of the so called 'abled' persons has been throbbing and diminishing. The circumstances of persons with disabilities may perhaps be horrifying or deteriorating with Covid-19 as many of them may find it difficult to vend for their "daily bread" and get an entrée to the apt information about Covid-19 that could keep them safe. Persons with disabilities (most especially those with mental health disorders) living in an overfilled hospice, institutional home or boarding facility may require the support of support staff to get food ready, cloth washed and other routine for their daily breathing. Nonconformity with the use of protective masks, hand sanitizer and few other measures by the operational staff of the boarding facilities while rendering services to persons with disabilities may get the individuals infected with Covid-19 and persons with disabilities respectively.

In addition, institutions, and camps for persons with disabilities are lacking cleansing agent and running water for the regular hand washing of persons with disabilities and their careers. This state of affairs together with the poor living environment and disheartened health-care amenities may impede an unending fight with Covid19 and it's spread amongst persons with disabilities insurmountable. Nevertheless, ban on interstate movement, social and religious gathering and schools' activities for days has incited the use of internet and application software deliberately design to run anthropological events with over twenty participants. Even though, the physical structures of office, classrooms and establishment are under the locked, their activities have been moved from conventional to the streamlined approach such as television, internet, and social media. Persons with disabilities if not being excluded, may not have fully benefited from this innovation owing to the absence of assistive devices or products such as digital outfits and internet amenities in addition to the problem of technical know-how and poor power supply (Human Right Watch, 2020). This might be termed as discrimination in the face of legal provision of education, information, health support for persons with disabilities to live like their counterparts without disabilities (Human Right Watch, 2020). Also, immeasurable number of digital information and guidelines to support school children at home through live broadcast may tend to be more beneficial to the 'abled' learners than those with disabilities because learning styles of persons with disabilities may not have been considered for its delivery.

For this reason, failure to reckon with uniqueness of persons with disabilities at all age may dispossesses Nigerian government from recognizing Covid-19 as a substantiated threat to the existence and essence of persons 
with disabilities. Meanwhile, series of practices such as working from home, paid leave; lithe functioning hour, televising and online based instruction and activities strictly adapted for persons with disabilities might intensify the fight against covid-19 pandemic, which may not be realistic and accessible to assistive devices. Assistive devices are very crucial for the rapid development and accomplishment of society by supporting persons with disabilities to bridge the existing gap in terms of access to cardinal information to be independent and acceptable. It is clear that assistive device is paramount for persons with disabilities to be invested, primed and aligned with their various societies. The advancement of technology in this present age as stated in Adewale (2014) makes it hard for the fulfillment of all-inclusiveness without incorporation of assistive devices. This is because assistive devices to persons with disabilities are getups and kits for independent, participation and instructions proficient of rewarding persons with disabilities for their deficiencies. Assistive devices have capacity for persons with disabilities to be peripatetic, acoustic, unified, and sighted using aids and service like speech synthesizer, lens and hearing aid as in the case of Stephen Hawking, and Tanko Alimakura. Thus, for persons with disabilities to be hale and hearty and relying less on social welfare scheme; lies in the correct blending of assistive devices. The raging short time of COVID-19 on humanity has call for inclusiveness.

\section{Covid-19 Pandemic and Persons with Disabilities}

The features of covid-19 as presented by Centre for Disease Control and Prevention (2020) is a sickness triggered by a specific virus from a group of viruses called corona virus which has been spreading from person to person all over the world. This unusual virus is not quite long but has overextended its host from animal to human (Singhal, 2020). It is on that corona virus is being described by World Health Organization (\{WHO\}, 2020) as a family of enormous viruses that causes disease from animals to human (Velava \& Meye, 2020). Corona virus as lay claim to by Perlman and Netland (2009) and Di Gennaro, Pizzol, Marotta, Antunes, Racalbuto, Veronese and Smith (2020) are "a ribonucleic acid infection with a classic crown-like form under an electron microscope in line for the presence of glycoprotein spikes on its envelope. Moreover, the findings of Hafeez, Ahmad, Ali-Siddqui, Ahmad and Mishra (2020) deeprooted seven(7) throngs of coronavirus's liable infectionsamong human but mostly by human corona virus $\mathrm{KU}$ 1, corona virus OC 43, corona virus 229 E, and that of corona virus NL 63 . However, Yin and Wunderink (2018) and Lu, Zhao, Li, Niu, Yang, Wu, Wang, Song, Huan g, Zhu, et al (2020) went further to dra $\mathrm{ft}$ corona virus into alpha corona virus, beta-corona virus, delta-corona virus, and gammacoronavirus. 
International Journal of Childhood, Counselling, \& Special Education (CCSE), Volume2, Issue: 1, March: 2021, pp.53-66

Inconsequence, alphacoronavirus based on the empirical evidence of Vijg en, Keyaerts, Moes, Thoelen, Wollants, Lemey, Vandamme and Van Ranst (20 05) comprises of corona virus $229 \mathrm{E}$ and human corona virus-NL 63. Betacorona virus as conversed in the study of Sastre, Dijkman, Camunas, Ruiz, Jebbink, van der Koek, Vela and Rueda (2017) take account of Hedgehog corona virus 1, Murine coronavirus, and the popular Middle East respiratory syndrome, Severe Acute Respiratory Syndrome, and Rousettus bat corona virus HKU 9, while delta-coronavirus according to the study conducted by Lau, Wong, Tsang, Ahmed, AU-Yeung, Yuen, Wernery and Woo (2018) covers species of corona virus like Bulbul corona virus HKU 11, white-eye corona virus HKU16, and corona virus HKU 13) the gamma-corona virus in the study of Milek and BlicharzDomanska (2018) entails Duck coronavirus 2714, Goose corona virus CB17, avian corona virus 9203 and Beluga Whale corona virus SW1 which are subgroups of corona virus. Thus, vectors hosting "alpha-corona virus" and "beta-corona virus" are said to be rodents and bat, while that of delta and gamma coronaviruses are being traced to whale and avian such as duck and goose. However, the studies of Hui, IA, Madani, Ntoumi, Kock, Dar et al. (2020) and Zhu, Zhang, Wang, Li, Yang, Song et. al. (2019) confirmed that covid-19 is the seventh associate of coronaviruses that passes disease unto humans, bats, and thick forest creatures.
The above findings were corroborated by Madani, Ntoumi, Kock, Dar, et al (2020) that covid-19 is a belta-coronavirus of group 2B. In that context, the causative agents of Covid-19 are domesticated in wild animals. However, Covid-19 is a taxonomy given by the World Health Organization to a disease instigated by the SARS-CoV-2 with its foundation traceable to a seafood market called Hunan situated in Wuhan city of China. The market is well famous among the Chinese for the sales of water and moist land creatures. The designation of a virus as Covid-19 was done on the $42^{\text {nd }}$ day of the year 2020 with its pandemic reputation not timehonored until 30 days after the pronouncement of its nomenclature. This according to Shereen and Khan (2020) and WHO (2020) could be due to snag in the activities of 108 countries or there about by this virus. Covid-19 is a true testifier to the aphorism that prevention is better than cure. This is because getting the victims of pandemic treated is convoluted; from unavoidable fourteen days of isolation to the running of array of medications on the infected patients. For now, humane immune virus-protease inhibitors together with nucleoside analogues treatment are being embraced in handling those in bad tastes of the pandemic after all no vaccine or antiviral remedy has been consented by World Health organization for Covid-19 pandemic. Still, a colossal figure of revisions has been submitted by experts. Wang, Tang and Wei (2020) established the 
chance of this pandemic ending its victim within forty-one days. There is not any iota of doubt that over one billion of persons inhabiting the globe (that is $15 \%$ of humanity) are likely to have been diagnosed with disabilities (World Health Organization and World Bank, 2011). Out of aforesaid demographic, not less than 20 million of such individuals might be living in Nigeria. The report of International Labour Organization (2020) showed that persons with disabilities are less able to fit into physical distancing directives. this could be due to their difficulty to procure germane information. Again, their overrepresentation among the poor in the society or in an informal economic activity increases their risk of infection. In the same way, Glad Network (2020) and Human Rights Watch (2020) both related the likelihood of persons with disabilities contracting Covid-19 to the poor cleanliness information, deprived health facilities, over-reliance on physical environment and needs to be supported by their able counterparts. Glad Network (2020) resolved that certain elements such as pre-existing health issues of the individuals and poor health services responsible for the greater risk of serious illness and death of persons with disabilities when infected with covid-19. Besides, Glad Network (2020) found persons with disabilities in residential institutions to be exceedingly predisposed to covid-19. Although, individuals with disabilities are constrained to contest with negative attitude such as exclusion, segregation and stigmatization prior to the arrival of Covid-19. These societal provocations in conjunction with health crisis experience and rout socioeconomic control have deepen the exclusion and marginalization of persons with disabilities during Covid19.

In addition, the empirical attestations from Groce and Kett (2014) connected unceasing discernment of persons with disabilities by their various societies; is liable to their imperfect right to health care services, malnutrition, lack of serene environment and sanitation, lack of safe water, integration into begging on the street, as well as their exposure to ferocity and abuse. Overlapping elements like sex, time of life (age) and humanitarian settings increase the prospect of persons with disabilities to exclusion (Glad Network, 2020). Additionally, economic commission for Latin America and the Caribbean (2019) argued that poor access to transportation; leisure and relaxation facilities are irrefutable impediments to free and independent living of persons with disabilities. This group of individuals is open to remoteness, unawareness and denial of support since outbreak of Covid-19. All the same, Covid-19 may disrupt therapeutic service, restoration outline, and reintegration supports designed for persons with disabilities in as much such service providers are expected to observe social distancing and restrict their movement as well. The underlying health conditions of persons with disabilities like that of 
breathing problem, poor immune system, diabetes, and heart disease may possibly lead to a multifarious and complicated incident of Covid-19 infection by such individuals. Persons with disabilities are likely to be more open to Covid-19 due to persistent difficulty in accessing their required nutritional supplements and medications with poor social defence and support for persons with disabilities by the general public.

Assistive Devices and Inclusion of Persons with Disabilities

Assistive device as it is being defined by STOA (2018) imply a thought-out instructions or services to improve the functional capabilities of persons with disabilities. World Health Organization (2017) viewed assistive devices as indispensible products for rewarding a loss of intrinsic capacity, reducing the consequences of gradual functional decline, need of care givers or prevention as well as helping to rationalize health and welfare costs. The assertion made by the above definitions is the confirmation of possibility of unravels the mysteries of all-inclusiveness in a time when the whole world is under the siege of Covid-19 pandemic by putting together all well initiated packages, intellectual, physical and human components. The World Health Organization (WHO, 2014) augured assistive devices as products, mechanisms, paraphernalia or know-hows specially designed or adapted to hone person with disabilities. In addition, World Health organization (2015) signified assistive devices as products or merchandises or technologies and related services. Often assistive devices which are used interchangeable with adaptive technology but does not absolute mean the same. Kazaure (2011) viewed assistive devices to be tools and mechanisms for independent, selfconfident, productive, and better integration of persons with disabilities into the mainstream. In the word of Ema (2011), assistive device is a prospect to overcome virtually all barriers where possibility is nebulous or ignore.

Mark (2002) presented assistive device as appropriate technology evolves by people in an attempt to meet the challenges of living in an environment. According to a widelyfavourite used definition given by IDEA (2004) otherwise known as Public Law 108-446 detailed assistive devices as piece of equipment that is either customized or modified to increase, maintain, or improve the functional competencies of person with disabilities. This given public law definition excluded any medical device that is surgically implanted from being referred to as assistive devices. Cook and Hussey (2000) given an appraisal about the IDEA's definition, the authors highlighted three major constituents rooted in the above definition as commercial, modified, and customized devices. Agreeing to the authors, the infusion of all types of devices covers a remarkable wide range of submissions. Secondly, this given definition emphasize is on the functional capabilities of an individual with disability. That is, by functional 
consequence the direction is being concentrating on the genuine measure of such implement. Using a device on the other hand specifically by a person with disabilities has to be an exclusive experience as claimed by PL law. It is on that the authors stated that no two devices are exactly the same in terms of practical ability, needs to serve and context in which th e achievement follow. Also, Duhaney a nd Duhaney (2000) marked assistive device as a fundamental tool in special needs education which makes instruction to be tailored towards meeting the necessities of an individual or a group of people. From this ongoing, assistive device is the channel to meet the outlays of distinctiveness in the society. Jane (2001) termed assistive device as a substitute tool for an omitted or declined function. In this context, assistive device are tools that provide support desirable to realize an undertaking. Jane's definition was in line with Lewis (1998) with the submission that "assistive devices are tools to offset the effects of disability; compensate for difference and provide a route line for getting a task accomplished. In consequence, the uses of assistive devices permit an individual or a group of persons with disabilities to be.

Assistive device as described by Behrmann (1998) in Adewale (2014), are products applied to increase, maintain, or improve the functional capabilities of persons with disabilities. For this reason, assistive devices are the only way of making society liveable for persons with disabilities due to its competency of increasing equity and improving the participation of persons with disabilities in all the events of societies (World Health organization, 2011; World Health organization, 2015). Several studies such as Netherton and Deal (2006); Parette and Peterson-Karlan (2007); Shore (2008); Scherer (2009); Ground, Lim and Larsson(2010); Borg, Larsson, Ostergren, Rahman, Bari, Khan and (2012a); Borg, Larsson, Ostergren, Rahman, Bari, Khan and (2012b); Bouck, Flanagan, Miller and Bassette (2012); Alquraini and Gut (2012) and Liman, Adebisi, Jerry and Adewale (2015) have not only confirmed the relevance of assistive device for inclusion of persons with disabilities, but had also signposted that assistive devices (that is in terms of products and services) are useful to persons with disabilities where movement, communication, eyesight and auditory perceptions might be so difficulty. The applicability of assistive devices could help persons with disabilities to gain access and enjoy their fundamental rights imbedded in the Disability Act of 2019, which are participation in accessible education, social and leisure events needed to boost physical, mental vigour of such individuals and in turn reduce their inter-dependent care.

In other word, assistive devices may possibly agree to make persons with disabilities manage their health, record school success and up for socioeconomic. Assistive devices can be in two forms; there are low-tech assistive as well as high tech (WHO, 2017; 
Adewale, 2014). The low tech as the name implies refers to products and services with a reasonably priced with less skill required for its operation. Assistive devices being classified as lowtech are mostly not operated with battery or voltage. The low-techs could be in form of orthotic, and prosthetic, crutches and spectacles for persons with visual impairment (WHO, 2017). The high techs on the other hand are computer-based products with meticulous demands for its operation. Aside that high-tech are more expensive and complex than low-tech. Whereas, products and services from cutting edge of science and technology being referred to as high-techs take account of augmentative communication, specialized computer hardware and software, voiceoutput application, structural ada ptations, speech synthesizers, screen reader, voice-recognition software, computer based package (such as voice computer word processing, spelling checker and automated dictionary), Braille printer, electronic image sensors and telescopic aids (Adewale, 2014; Akpan \& Beard, 2013; Moore, 2012). Although, the ratification of Disability Act by Nigeria has not only supported the use of assistive devices or products as necessity but confirmed it to be an integral part of persons with disabilities for the realization of sustainable development goals in the country. Yet, factors such as financial implication, unavailability, awareness and skilful personnel to mention but a few are hurdles for the acquisition of assistive devices.

\section{Conclusion}

There is no supernumerary for inclusiveness needs in all responses to COVID-19 and related humanitarian interventions, from health preventive measures to social protection responses. Discrimination in access to COVID-19 information and life-saving procedures and equipment by persons with disabilities is a serious human rights violation. Failure to consider disaggregation of epidemiological data by disability may divests a less developed country like Nigeria from comprehending the magnitude of the impact of Covid-19 as well as undervalues the life experiences and contributions of persons with disabilities to the community. Without accessible digital information, it is difficult to fully understand Covid-19, its impact on persons with disabilities; and consequently, limits the possibilities to ensure equitable and/or targeted services to such individuals. Assistive devices may have proven to be very expedient to the actualization of inclusive environment. Thus, definite assistive devices developed to maintain and promote the well-being of persons with disabilities could be highly appreciative not in any other better time than now. This is because assistive device is not only a riposte to the actively self-directed linkage between persons with disabilities and access to health, education, labour force and social life. In a nutshell, assistive devices could be instrumental in the fight against Covid-19 as persons with disabilities (both old and young) are met to be fortified through its efficacy. 


\section{Recommendations}

1. Accessible purgative conveniences should be installed in all institutional homes of persons with disabilities

2. Protective materials such as face shield/nose marks, soaps and hand sanitizers are to be delivered to all institutional homes for the enforcement of regular hand washing by persons with disabilities and their support staff or care givers.

3. Alternate models of communication such as sign language and facial lexes on hand washing procedure should be adopted

4. Technicians should be empowered to fabricate affordable assistive devices

5. Ministry of science and technology should be more proactive.

6. Sufficient funds should be made available for evidence-based research on the production of assistive devices.

\section{Reference}

Adewale, H. G. (2014). Efficacy of assistive technology on educational programs of students with learning disabilities in an inclusive setting in Jos North Local government Area of Plateau state, Nigeria. Unpublished Bachelor of Science in Education project of University of Jos, Nigeria.

Akpan, J. P., \& Beard, L, A. (2013). Overview of assistive technology possibilities for teachers to enhance academic outcomes of all students. Universal Journal of Educational Research
1(2):

113-118,

DOI:

10.13189/ujer.2013.010211.

Alquraini, T., \& Gut, D. (2012). Critical components of successful inclusion of students with severe disabilities: Literature review. International Journal of Special Education, 27(1), 42-59.

Borg, J., Larsson, S., Östergren, P. O., Rahman, ASMA., Bari, N., \& Khan, A. N. (2012). Assistive technology use and human rights enjoyment: a crosssectional study in Bangladesh. BMC International Health and Human Rights, 12 (18), 233-245.

Borg, J., Ostergren, P. O., Larsson, S., Rahman, A. A., Bari, N. \& Khan, A. N. (2012). Assistive technology use is associated with reduced capability poverty: A cross-sectional study in Bangladesh. Disability and Rehabilitation Assistive Technology, 7 (2),112-121, https://doi.org/10.3109/17483107.2011. 602173.

Bouck, E. C., Flanagan, S., Miller, B., \& Bassette, L. (2012). Rethinking everyday technology as assistive technology to meet students' IEP goals. Journal of Special Education Technology, 27(4), 47-57.

Center for Disease Control and Prevention. (2020). Coronavirus disease 2019 (COVID-19). https://www.cdc.gov/coronavirus/2019nc ov/symptomstesting/symptoms.html Cook, A. M., \& Hussey, S. M. (2002). Assistive Technologies: Principle and Practice (2 ${ }^{\text {nd }}$ Edition). University of Michigan: Mosby incorporation.

DiGennaro, F., Pizzol, D., Marotta, C., Antunes, M., Racalbuto, V., Veronese, N., \& Smith, L. (2020). Coronavirus diseases (COVID-19) Current status 
International Journal of Childhood, Counselling, \& Special Education (CCSE), Volume2, Issue: 1, March: 2021, pp.53-66

and future perspectives: A Narrative review. International Journal of Environmental Resources and Public Health, 17, 2690, doi:10.3390/ijerph17082690.

Duhaney, L. M., \& Duhaney, D. C. (2000). Assistive technology: Meeting the needs of learners with disabilities. International Journal of Instructional Media. 27, 393-402.

Ema, E. (2011). Assistive technology as a tool for reasonable accommodation for Persons with Special Needs in Nigeria. In A. Olabisi (Ed.), Child Care and special Need's education in Nigeria. (Pp. 59-67. Centre for learning Disabilities and Audiology.

Glad Network. (2020). Global action on disability network statement on persons with disabilities in the COVID19 outbreak and response. https://gladnetwork.net Groce, N., \& Kett, M. (2014). Youth with disabilities (Working Paper Series: No. 23). London:

Leonard Cheshire Disability and Inclusiv e Development Centre. https://www.ucl.a c.uk/lcccr/centrepublications/workingpaper s/WP23 Youth with Disabilities.pdf Ground, A., Lim, N., \& Larsson, H. (2010). Effective use of assistive technologies for inclusive education in developing countries: Issues and challenges from two case studies. International Journal of Education $\mathcal{E}$ Deve lopment using Information $\mathcal{E}$ Communication Technology, 6(4), 5-26.

Hafeez, A., Ahmad, S., Ali S. S., Ahmad, M., \& Mishra, S. (2020). A review of COVID-19 (coronavirus disease-2019): Diagnosis, Treatments and Prevention. European J ournal of Medicine and Oncology, 4(2), 4(2),

DOI: 10.14744/ejmo.2020.90853.

Hui, D. S., Ia, E., Madani, T.A., Ntoumi, F., Kock, R., Dar, O., et al. (2020). The continuing $2019-\mathrm{nCoV}$ epidemic threat of novel coronaviruses to global health - the latest 2019 Novel coronavirus outbreak in Wuhan, China. International Journal of Infectious. Diseases. 91, 264-266, https://doi.org/10.1016/j.ijid.2020.01.00 9.

Human Rights Watch (2020). Making sure people with disabilities get their rights during Covid-19

Individuals with Disabilities Education (IDEA). (2004). Improvement Act of 2004, Pub. L.aw of United States of America, No. 108-446.

International Labour Organisation (ILO). (2020). Policy Brief: COVID-19 and the World of Work: Ensuring the inclusion of persons with disabilities at all stages of the response Review

Kazaure, K. A. (2002). The role of Assi stive Technology as a tool for reasonabl e Accommod-ation for Persons with Special Needs in Nigeria. In A. Olabisi (Ed.), Child care and special needs education in Nigeria, Vol. 3 (1). (Pp. 134140. Centre for Learning Disabilities and Audiology

Lau, S. K. P., Wong, E.Y.M., Tsang, C. C., Ahmed, S. S., AU-Yeung, R. K. H., Yuen, K.Y., Wernery, U., \& Woo, P.C.Y. (2018). Discovery and sequence Analysis of Four Deltacoronavirus from birds in the Middle East reveal Interspecies Jumping with $\mathrm{r}$ ecombination as a potential Mechanism for Avian-to-Avian-to- 
Mammalian Transmission. Journal of Virology, 92 (15), e00265-18. Doi: 10.1128/jvi.00265-18.

Lewis, R. B. (1998). Special education technology classroom Applications. CA.

Liman, A. N., Adebisi, R. O., Jerry, E. J \& Adewale, H. G. (2015). Efficacy of Assistive Technology on the Educational Program of Children with Learning Disabilities in Inclusive Classrooms of Plateau State, Nigeria. International Journal of Educational Policy and Entrepreneurship Research, 2 (2), 23 . 32.

Lu, R., Zhao, X., Li, J., Niu, P., Yang, B., Wu, H., Wang, W., Song, H., Huang, B., Zhu, N., et al. (2020). Genomic characterization and epidemiology of 2019 novel coronavirus: Implications for virus origins and receptor binding. Lancet, 395, 565-574.

Mark, S. (2002). Technology Ethnography and its Limits. California Publication.

Milek, J., \& Blicharz-Domanska, K. (2018). Coronavirus in Avians SpeciesReview with focus on epidemiology and diagnosis in wild birds. Journal of veterinary research, 62(3) 249.

255. Doi:10.2478/jvetres. 20180035.

Moore, K. D. (2012). Effective instructional strategies from theory to practice. Sage.

Netherton, D. L. (2006). Assistive technology in the classroom. Technology Teacher, 66 (1), 10-15.

Parette, H. P., \& Peterson-Karlan, G. R. (2007). Facilitating student achievement with assistive technology.
Education and Training in Developmental Disabilities, 42 (4), 387-397.

Perlman, S., \& Netland, J. (2009). Coronaviruses post-SARS: Update on replication and pathogenesis. Nat. Rev. Microbiol.

$$
7 \text {, }
$$

439-450, https://doi.org/10.1038/nrmicro2147.

Rothan, H. A. \& Byrareddy, S. N. (2020). The epidemiology and pathogenesis of coronavirus disease (COVID19) outbreak. Journal o f Autoimmunity, https://doi.org/10.1016 /j.jaut.2020.102433.

Sastre, P., Dijkman, R., Camunas, A., Ruiz, T., Jebbink, M. F., van der Koek, L., Vela, C., \& Rueda, P. (2017). Clinical laboratory immunology: Differentiation between human Coronaviruses NL63 and 229E using a Novel Double-Antibody sandwich Enzyme-linked Immuno sorbent Assay Based on specific Monoclonal antibodies. Journal of Clinical and Vaccine Immunology. Doi:10.1128/cvi.00355-10.

Scherer, M. J. (2009). Assistive technology and persons with disabilities. In M. I. \& Stebnicki, M. (Eds.), Professional counselor desk reference. (p. 735-746). Springer Publishing Co.

Shereen, M. A., Khan, S, (2020). COVID-19 infection: origin, transmission, and characteristics ofhuman coronaviruses. Journal of Adva nced Research, 24, (1), 91 - 94. https://www.sciencedirect.com/science/a rticle/pii/S2090123220300540

Shore, S. L. (2008). Use of an economical wheelchair in India and Peru: Impact on health and function. Medical Science Monitor, 14(12), 71-79. 
International Journal of Childhood, Counselling, \& Special Education (CCSE), Volume2, Issue: 1, March: 2021, pp.53-66

Singhal, T. (2020). A Review of coronavirus disease-2019 (COVID-19). Indian Journal of Paediatrics, 87 (1), 281 . 286. https://doi.org/10.1007/s12098020-03263-6.

STOA - Science and Technology Options Assessment. (2018). Assistive technologies for people with disabilities Indepth analysis Assistive technologies in Europe: legal and ethical reflections. The Scientific Foresight Unit (STOA): European Parliamentary Research Service, European Parliament. IP/G/STOA/FWC/2013-001/LOT 6/C3; PE 603.218. Doi: $10.2861 / 42217$.

The Economic Commission for Latin America and the Caribbean (ECLAC). (2020). COVID-19 Reports: Persons with disabilities and coronavirus disease (COVID-19) in Latin America and the Caribbean: status and guidelines The Economic Commission for Latin America and the Caribbean (ECLAC). (2019). Critical obstacles to inclusive social development in Latin America and the Caribbean: background for a regional agenda (LC/CDS.3/3), Santiago

Velavan T. P., \& Meyer, C. G. (2020). The COVID-19 epidemic. Tropical Medical

International Health, 25(3), 278280. doi:10.1111/tmi.13383.

Vijgen, Lee., Keyaerts, Els., Moes, Elien., Thoelen, Inge., Wollants, Elke., Lemey, Philippe., Vandamme, AnneMieke \& Van Ranst, Marc (2005). Complete Genomic Sequence of Human coronavirus OC43: Molecular Clock analysis suggests a Relatively Recent Zoonotic Coronavirus
Transmission Event. Journal of virology: American society of Microbiology. Doi:10.1128/jv1.79.3.1595-1604.2005.

Wang, H., Wang, S., \& Yu, K. (2020). COVID-19 Infection epidemic: The medical management strategies in Heilongjiang Province. China Critical Care, 24, 107.

Wang, W., Tang, J \& Wei, F. (2020). Updated understanding of the outbreak of 2019 novel coronavirus (2019-nCoV) in Wuhan, China. Journal of Medical Virology, 92 (4), 441447. https://doi.org/10.1002/jmv.25689. World Health Organisation (WHO). ( 2020). Report on Coronaviruses (COVID

19). https://www.who.int/news-room/qa-detail/q-a-coronaviruses

World Health Organisation. (2014). Chapter 1 Products and technology. World health organization. http://apps.who.int/classifications/icfbro wser/.

World Health Organisation \& World Bank. (2011). World report on disability, summary

report. WHO. http://whqlibdoc.who.int/h q/2011/WHO NMH VIP 11.01 eng.pdf. World Health Organisation. (2017). Deafness and hearing loss. Fact sheet. World Health Organization. http://www.who.int/mediacentre/factshe ets/fs300/en/

World Health Organisation. (2008). The global burden of disease. 2004 update. World Health Organization.

World Health Organisation. (2011). Joint position paper on the provision of mobility devices in less -resourced settings: a step towards implementation of the Convention on the Rights of Persons with Disabilities (CRPD) related to personal mobility. World Health Organization. 
International Journal of Childhood, Counselling, \& Special Education (CCSE), Volume2, Issue: 1, March: 2021, pp.53-66

World Health Organisation/United Nations Children's Fund. (2015). Assistive technology for children with disabilities: Creating opportunities for education, inclusion and participation - A discussion paper. www.who.int

World Health Organization (2020). Infection prevention and control during health care when COVID-19 is suspected. https://www.who.int/publicationsdetail/infection-prevention-and-controlduring-health-care-when-novel-coronavirus(ncov)-infection-is-suspected-20200125.

World Health Organization. (2008). Guidelines on the provision of manual wheelchairs

less resourced settings. World Health Org anisation. http://www.who.int/disabilitie s/publications/technology/English\%20W heelchair\%20Guidelines\%20(EN\%20for \%20the\%20web).pdf?ua $=1$.

World Health Organization. (2016). Assistive technology. Fact sheet. World Health Organisation. http://www.who.i nt/mediacentre/factsheets/assistive-

technology/en/.

World Health Organization. (2020). Director-General's Opening Remarks at the Media Briefing on covid19 on the 11 March 2 020. https://www.who.int/dg/speeches/ detail/who-director-general-sopeningremarks-at-the-media-briefing-oncovid-19--11-march-2020.

World Health Organisation. (2011). W orld report on disability. World Health $\mathrm{O}$ rganization.

Yin, Y., Wunderink, R. G. (2018). MERS, SARS and other coronaviruses as causes of pneumonia. Journal of Respirology, 23, 130-137.

Zhu, N., Zhang, D., Wang, W., Li, X., Yang, B., Song, J. et al. (2019). A novel coronavirus from Patients with pneumonia in Chin a. N. Engl. J. Med, 382, 727733. https:// doi.org/10.1056/NEJMoa20010172020. 